\title{
Engaging Students of English Program in a Real Business Activity as an Effort to Create New Millennials Entrepreneurs
}

\author{
Setia Muljanto ${ }^{1}$, Eva Devy $\mathrm{S}^{2}$, Pipih Setiawati ${ }^{3}$, Amir Hamzah $^{4}$ \\ \{setiamuljanto@institutpendidikan.ac.id ${ }^{1}$, evadevi@institutpendidikan.ac.id ${ }^{2}$, \\ pipih@institutPendidikan.ac.id $\left.{ }^{3}\right\}$ \\ Institut Pendidikan Indonesia, J1. Pahlawan No. 32, Garut - West Java, Indonesia ${ }^{1,2,3,4}$
}

\begin{abstract}
Indonesia needs a lot of new entrepreneurs to explore our natural resources and indigenous technology and to strengthen our country's economy. However, business is often viewed as a difficult act by the students of English Program. English for Business and Economy (EBE) course is intended to provide students with real business activities. The research problem focussed on whether the curriculum devised for EBE can effectively engage students in a real business activity. The aim of this study was to find out students engagement in business and to give a better understanding on EBE curriculum and to give them motivation to become new millenials entrepreneurs. To answer the research problem, we use Likert scale survey on google form which was distributed to 110 students and also their opinion was recorded by open-ended questions. The result of the research showed that the students appreciate business and are inspired to begin their own business ventures. To conclude, EBE curriculum has potential impact in creating new millennials entrepreneurs as our country needed.
\end{abstract}

Keywords: business activity, English for Business and Economy, millennials entrepreneurs

\section{Introduction}

Most students of English department at Indonesia Institute of Education (IPI) are not familiar with business and economy concept. The department curriculum is focussed on teaching English and language skills to be mastered. These courses are intended to prepare, to shape and train students to become good teachers of English in the future. However, reality nowadays shows that by only becoming teachers, most of the time, is not enough to earn income for their basic needs. University as a leading institution has the obligation to shape students as agents of change. Students need to create new opportunities to improve and make contribution to their own society. One of the choices is to become an entrepreneur [1].

The fact shows that income as a professional that teachers received are often not sufficient to fulfil their basic needs, so this lead to unprofessional conduct done by the teachers during teaching [2]. Therefore, English Program at IPI developed some adjustments to the curriculum as to include English for Business and Economy as an obligatory course to be taken by the students to enhance their understanding on business and economic issues as well. This inline with an expectation that by learning the basic concept of business, the students could have 
a better chance to have alternative income from their business and also improve their life in the future [3].

This research was attempted to find out whether by taking EBE courses, students could increase their knowledge on business as a specific activity and also improve their understanding of the economy concept in general.

\section{The content of English for Business and Economy Curriculum}

Most of the time at the beginning of their career as a teacher, new teachers received an only a small amount of salary. To make ends meet, teachers need to be creative [3]. One of choice to sustain their life, is to become an entrepreneur. English for Business and Economy (EBE) was placed into an English Program curriculum at IPI as a way to fulfill that economy need. EBE has a unique set of lesson plans. The course was intended to make students aware of their needs and gain personal belief [4] in the future.

This research also found out that English for Business has encouraged students to master English vocabularies in which more specifically on business terminology (see Fig. 1) in advance to their previous general English knowledge. In the EBE curriculum and syllabus, it stated that the goal of the course is to make students able to use those vocabularies and implement them into daily activities.

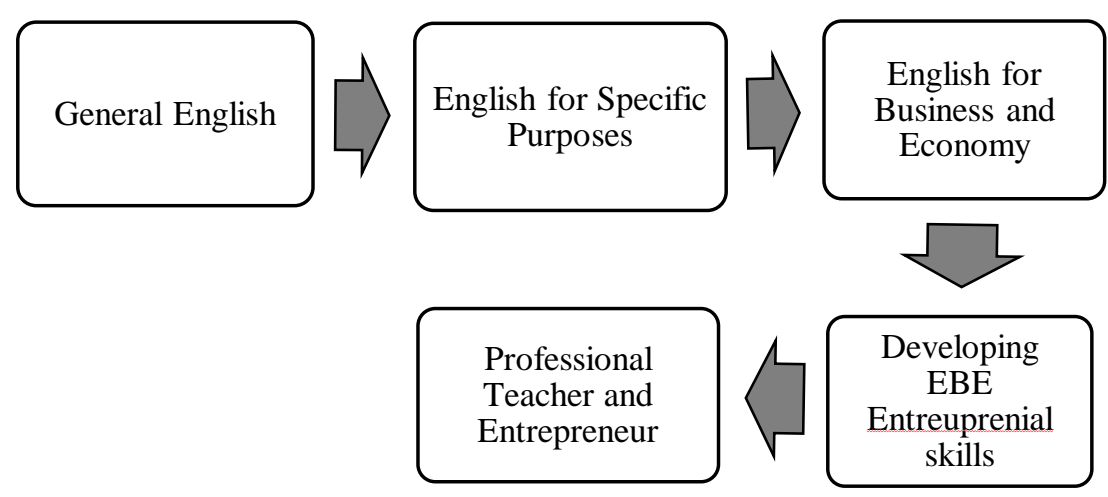

Figure 1. The flow of developing English students skills

There are abundant variations in the activities constructed in EBE curriculum. Besides the introduction to the terminology, there was a theme called one day job, in which each student need to experience being an apprentice for just one day. Some of them became a sales promotion girl; others sold their abilities to translate papers from customers. The second theme was to make recycled products from an old unused pair of jeans. Here the students as a group collaboratively designed a pattern for a bag, shoes, and even a purse of their choices. Then they had to present and explain the process of making recycled products. The main goal for this activity is to introduce millennium development growth which relies on the eco-friendly product. The 
concept of reducing, reusing and recycling has to be introduced in the institution curricula, in which EBE has pioneered.

The highlight of the EBE course was to make culinary product as the main project. This group work involved three to four students. The activity starts by discussing the product, the name of the company, logo of the company and organization structure. The activities were followed by making a marketing brochure and merchandise. Then the final phase was selling the product at the bazaar as the EBE course final exam. The evaluation was based on the product sold and the use of English as mediatory language during the bargaining process with the customers.

\section{Research Methodology}

Research participants include 105 participants, 88 female and 17 male students. These research participants come from 4 different class of EBE course. They are between 18 to 23 years old. They have participated in this research by filling data survey from google form which was distributed during the research. The form comes into two parts. In the first part, the research participants have to answer 20 questions about their understanding of business and economy. The questionnaires were then to be answered according to the Likert scale that was given by the researchers. The second part of the form is open-ended questions, which consist of 5 probing questions to be answered according to the participant's opinion on the EBE course experiences. The nature of the data obtained was to give the best description of a real situation at a given time duration [5].

\section{Results and Findings}

By observations into EBE class, the researchers noted vocabularies on banking, business, trading and economy were introduced at the beginning of the course. Then these vocabularies were reviewed in the forms of formative test and evaluation. Vocabulary building increased the students understanding of the world of business [6]. From the questionnaire, specifically, question 1 to 4 the majority of the students understood and gained more insight about business and economy during the activity in the class (see Fig.2).

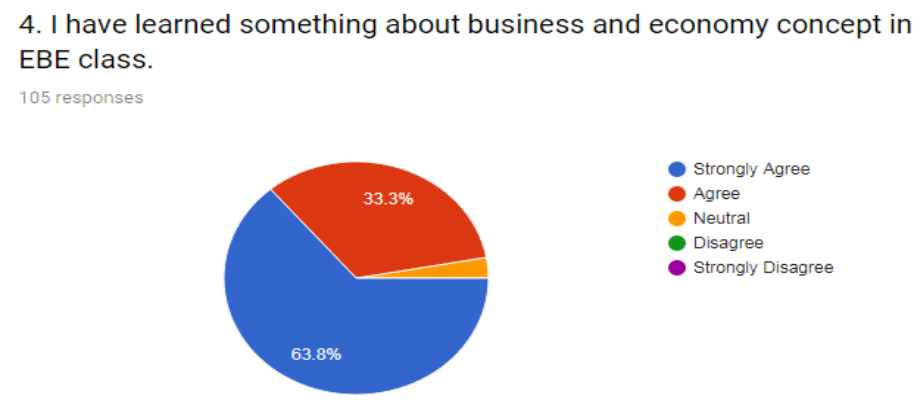

Figure 2. Students response on EBE class 
Students response to their expectations for the future in building the business was surprisingly high. The response shows their motivation was linear through the experiences they obtain during the EBE class and that they used the internet to find information to start up a business of their own; this was no. 5 to 9 on the questionnaire (see Fig.3). Startup business has been the focus of our country nowadays in the hope of bringing back the glory of Indonesia [7].

\section{I think that after taking EBE class I'm more confident to start my own business.}

105 responses

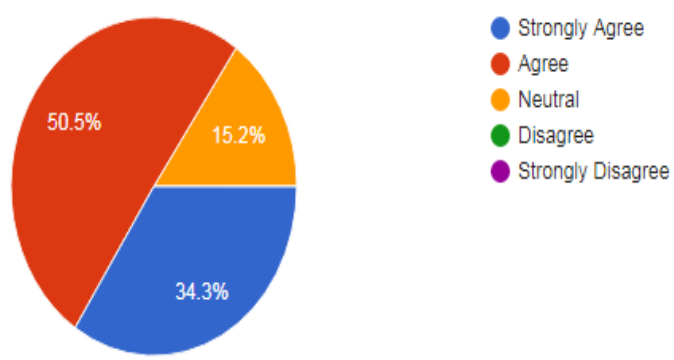

Figure. 3 Students response in starting a business

The result of the results also showed that students as the participants of the research had enjoyed the atmosphere of EBE course throughout the semester. They think that the course offered them many opportunities and a lot of variation of the activities conducted during the course, this was the asked on questions 10 to 15 (see Fig. 4)

10. I have enjoyed and a lot of fun in joining EBE class.
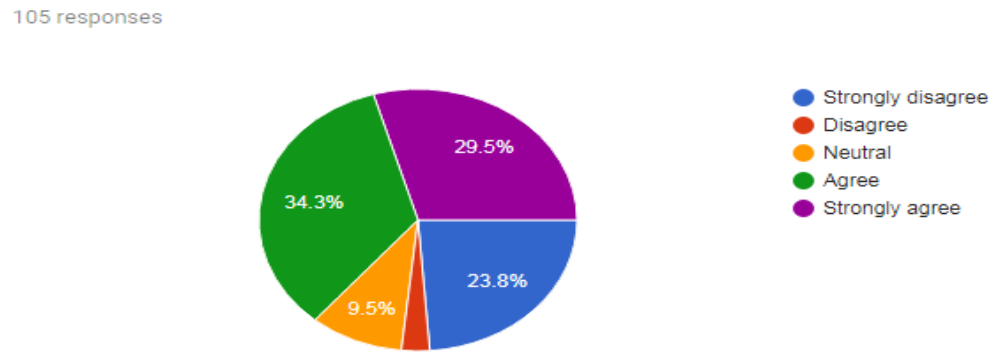

Figure 4. Students enjoyed a conducive atmosphere classroom

From question no. 15, the researchers found out that the use of multimedia also has increased students understanding during a group presentation. They used various media to show and explain their understanding of the products they have made. Internet literacy comes to research. The students also worked hard to obtain information from the internet (question 1620). Information on business articles, businessman profile and also start-up business they explored further through online activities. 


\section{Conclusions}

This research, based on the findings and the results, concludes that the curriculum and course design of English for Business and Economy could engage English Program students in business activities. The students enjoyed and participated actively in every business activities such as designing the product, creating packaging for their product and finally selling the product to the schools' society.

Most of the students were so inspired by EBE business activities that they make plans to start their businesses. From the group assignments, some of the group members have decided to make a real business as their side job besides finishing their study at the Indonesia Institute of Education.

Some of the students have turned themselves into new millennials entrepreneurs. The students have committed themselves to plan, organize, do actions and control their future business. The implication of the course could give them a new hope to have a better future to become professional teacher as well as a successful entrepreneur, or what we liked to call them "Gurupreneur"

\section{Acknowledgments}

The researchers would like to extend gratitude to the students of English Program, Dr Lina Siti Nurwahidah as the Dean of Education for Social Sciences Language and Literature Faculty, and Dr Nizar Alam Hamdani as the Rector of Indonesia Institute of Education for all the support and motivation given to the researchers.

\section{References}

[1] Adyatma, P and E. Yulianna.: Factors Analysis That Influence The Interest Of Entrepreneurial Students (Research On International Students Telkom University 2011 2015). E-Proceeding Of Management: Vol.4, No.1. pp. 82-86 (2017)

[2] Slameto S., Permasalahan-permasalahan terkait dengan guru SD. Scholaria: Jurnal Pendidikan dan Kebudayaan, vol. 4 No 3. pp 1-12. p-ISSN 2088-3439, e-ISSN 25499653, UKSW- Salatiga..

https://doi.org/https://doi.org/10.24246/j.scholaria.2014.v4.i3.p1-12

[3] Permendiknas No. 16 of 2007 on Academic Qualification Standards and Teacher Competencies.

[4] Wyatt, Mark, An English teacher's developing self-efficacy beliefs in using groupwork, University of Portsmouth, School of Languages and Area Studies, Park Building, King Henry I Street, Portsmouth, Hampshire PO1 2DZ, UK Received 11 April 2010; revised 8 August 2010; accepted 18 August 2010 
[5] Bogdan, R.C. and Biklen, S.K. 2007. Qualitative Research for Education: an Introduction to Theories and Methods, 5th ed. Allyn and Bacon. Boston, MA.pp.274

[6] Basturkmen, Helen: Ideas and options in English for specific purposes, Lawrence Earlbaum Associates, Taylor and Frances, 2008

[7] Shimizu,Tamio, de Carvalho, and Laurindo: Strategic alignment process and decision support systems : theory and case studies /. IRM Press, (2006).pp.158 